\title{
KOMUNIKASI PEDAGOGIS PENDIDIKAN TINGGI KEHUTANAN DALAM PERSPEKTIF KRITIS
}

\section{Pedagogical Communication in High Forestry Education in Critical Perspective}

\author{
Mutiono $^{1}$, Sarwititi Sarwoprasodjo ${ }^{2}$, Sudarsono Soedomo ${ }^{3}$, Heri Budianto ${ }^{4}$ \\ ${ }^{1}$ Program Studi Komunikasi Pembangunan Pertanian dan Pedesaan IPB \\ ${ }^{2}$ Fakultas Ekologi Manusia IPB \\ ${ }^{3}$ Fakultas Kehutanan IPB \\ ${ }^{4}$ Fakultas Ilmu Komunikasi Universitas Mercu Buana Yogyakarta \\ E-mail : mas.muti1992@gmail.com
}

\begin{abstract}
The emergence of various forest resources problem in Indonesia, pragmatically could not be launched from the processes that occured in higher education. As a manifestation of development communication events, pedagogical communication that occurs in forestry education was important to be observed. This paper aims to explain the facts that occured in the teaching and learning process at the selected Faculty of Forestry, including to explain epistemology that form those facts. The research paradigm is a critical paradigm in qualitative research. Samples were taken purposively by conducting classroom observations, in-depth interviews with students and lecturer, desk study and conducting Focus Group Discussion. The results of this research show that there are facts which lead to the ineffectiveness of pedagogical communication. There are at least 8 issues that became the impetus for the occurrence of such ineffectiveness. The situation has made the message construction thus was not carried but only administrative issues answered in ongoing pedagogical communication. It makes a silent culture increasingly wide spread and inquiries that build students awareness of being not able to grow.
\end{abstract}

Keywords: educational pragmatism, pedagogical communication, communication effectiveness, silent culture

\begin{abstract}
ABSTRAK
Munculnya berbagai persoalan dalam pengelolaan sumber daya hutan di Indonesia secara pragmatis tidak dapat dilepaskan dari proses yang terjadi dalam pendidikan tinggi kehutanan. Sebagai salah satu wujud dari peristiwa komunikasi, proses transfer ilmu pengetahuan yang terjadi dalam pendidikan kehutanan menjadi penting untuk diamati. Tujuan penelitian ini adalah mengungkap faktafakta yang terjadi dalam komunikasi pedagogis di Fakultas Kehutanan terpilih serta mengungkap berbagai faktor yang membentuk fakta tersebut. Paradigma penelitian yang digunakan adalah paradigma kritis melalui pendekatan kualitatif. Sampel diambil secara purposif dengan melakukan observasi kelas, wawancara mendalam dengan dosen dan mahasiswa, studi dokumen dan fokus grup diskusi. Hasil dari penelitian ini menunjukkan bahwa masih terdapat fakta-fakta yang mengarah pada ketidakefektifan komunikasi. Setidaknya terdapat 8 persoalan yang menjadi pendorong terjadinya ketidakefektifan tersebut. Situasi yang ada telah membuat pesan pembangunan justru tidak tersampaikan melainkan hanya
\end{abstract}


persoalan administrasi yang terjawab dalam komunikasi pedagogis yang berlangsung. Hal tersebut membuat budaya bisu semakin meningkat dan kekritisan yang membangun kesadaran mahasiswa menjadi tidak mampu tumbuh.

Kata kunci: pragmatisme pendidikan, budaya bisu, efektivitas komunikasi, komunikasi pedagogis

\section{PENDAHULUAN}

Komunikasi pembangunan, pada praktiknya dapat terkonstruksi ke dalam berbagai ragam kegiatan tergantung bentuk dan tujuan pembangunan yang akan diwujudkannya. Salah satu bentuk konstruksi komunikasi pembangunan yang dapat dengan mudah ditemui dalam kehidupan sehari-hari adalah pendidikan. Pendidikan merupakan cerminan proses komunikasi yang di dalamnya membawakan pesan-pesan pembangunan sehingga institusi pendidikan diharapkan mampu berperan dalam menjawab berbagai persoalan pembangunan (Oey-Gardiner dkk 2017). Proses transfer pesan dalam konteks pendidikan tersebut oleh Prucha (1986) disebut sebagai komunikasi pedagogis.

Kerusakan sumberdaya hutan Indonesia oleh berbagai sebab yang saling berkaitan menunjukkan telah terjadinya berbagai kegagalan termasuk kegagalan pendidikan (Foretika 2005). Pendidikan tinggi merupakan sebuah institusi sosial yang tidak dapat dianalisis terpisah dari konstalasi sosial, politik dan ekonomi masyarakat yang melingkupinya, oleh sebab itu gagalnya peran pendidikan tinggi dalam menjawab berbagai tantangan bangsa dan kemanusiaan akan membuahkan krisis yang serius kepada masa depan bangsa, negara dan umat manusia (Afiff 2005).

Berbagai data yang diungkap oleh Forest Watch Indonesia (2013) tentang kerusakan biofisik hutan, Komisi Nasional Hak Asasi Manusia (2014) tentang berbagai pelanggaran HAM masyarakat di sekitar kawasan hutan, DEPHUT (2009) dan KLHK (2016) tentang merosotnya bisnis kehutanan yang dikelola swasta, Soedomo (2013) tentang berbagai kegagalan pembentukan kebijakan kehutanan, Setiawan dkk (2017) tentang korupsi bidang kehutanan, Nugroho (2011) dan Nugroho (2017) tentang tidak berkembangnya program-program perhutanan sosial, Soedomo (2010) tentang kegagalan bisnis kehutanan yang dikelola negara, serta beberapa hasil penelitian dari Santoso (2008), Suharjito (2011), Ina (2011), Marina \& Dharmawan (2011) dan Konsorsium Pembaharuan Agraria (2014) tentang berbagai konflik dalam pengelolaan sumber daya hutan, seluruhnya telah menunjukkan berbagai persoalan yang dihadapi oleh sektor kehutanan baik di level biofisik, sosial, ekonomi, politik hingga kemanusiaan. Terjadinya berbagai persoalan tersebut secara pragmatis menunjukkan juga adanya kegagalan pendidikan tinggi kehutanan dalam menjawab tantangan pengelolaan sumberdaya hutan. Berdasarkan asumsi tersebut, maka diperlukan adanya penelusuran secara kritis praktik pendidikan di perguruan tinggi untuk dapat mengetahui secara lebih rinci bagaimana praktik pendidikan berlangsung sehingga dapat dipahami letak potensi yang menimbulkan kegagalan pendidikan dalam menjawab berbagai tantangan persoalan.

Soedomo (2013) memicu hal tersebut dengan menyebutkan bahwa lembaga pendidikan berpotensi menjadi lembaga penerus hipnotis masal dan berbagai doktrin serta tidak mampu membangunkan jiwa peserta didiknya sehingga gagal menyiapkan lulusannya untuk berani sadar, memiliki daya gugat dan berani hidup 
menjadi dirinya sendiri yang terbebas dari penindasan, pembodohan dan ketertinggalan. Sistem pendidikan seperti itu oleh Paulo Freire disebut sebagai sistem pendidikan bergaya bank (bank concept of education) yang dijalankan melalui model bercerita (narrative), menggurui dan hafalan sehingga menumbuhkan kebudayaan bisu (the culture of silent) yang membuat peserta didik tidak mampu menerjemahkan pengetahuan ke dalam realitas sosial dan justru membentuk kefanatikan (Freire 2002, de Bono 2009, Soedomo 2012, Hidayat 2013, Freire 2016). Hal tersebut berpotensi terjadi pada lembaga pendidikan tinggi kehutanan sebagaimana telah ditunjukkan dengan berkembangnya fenomena doktrin scientific forestry di perguruan tinggi kehutanan dan masih banyaknya kekeliruan berfikir (fallacy) yang dianggap sebagai kebenaran tanpa adanya daya gugat dalam proses pendidikan kehutanan (Gluck 1987, Soedomo 2012, Soedomo 2013, Kartodihardjo 2013). Oleh sebab itu, penelitian ini difokuskan pada penelusuran praktik pendidikan secara kritis dalam proses belajar mengajar di perguruan tinggi kehutanan untuk memperoleh berbagai fenomena dalam proses belajar mengajar beserta mengungkap berbagai faktor penyebabnya.

Persoalan komunikasi pembangunan kritis sebagaimana dijabarkan diatas dalam wujud komunikasi pedagogis yang berlangsung pada pendidikan tinggi, hingga saat ini belum banyak menjadi perhatian. Komunikasi pembangunan kritis yang pada berbagai publikasi juga disebut sebagai komunikasi pembangunan partisipatif telah banyak dikembangkan dalam obyek studi pendidikan informal, pengembangan masyarakat dan penyuluhan (Rinawati 2006, Dilla 2007, Hadiyanto 2008). Oleh sebab itu, penelitian ini menjadi penting sebagai permulaan penelitian komunikasi pembangunan yang berfokus pada pendidikan tinggi sebagai sebuah autokritik terhadap institusi yang memiliki peran besar dalam mendidik generasi yang akan turut serta pada pembangunan bangsa Indonesia di berbagai bidang.

\section{METODE PENELITIAN}

Penelitian ini dilaksanakan pada bulan April hingga Oktober 2018 di Fakultas Kehutanan X. Fakultas Kehutanan X merupakan salah satu fakultas kehutanan yang menjadi model acuan untuk penyusunan kurikulum dan penyelenggaraan pendidikan tinggi kehutanan di Indonesia (Sastrosumarto 2005).

Penelitian ini berlandaskan paradigma kritis. Berangkat dari paradigma tersebut, untuk menggali makna yang terdapat dibalik realitas yang dihadapi, penelitian ini menggunakan pendekatan kualitatif. Pendekatan kualitatif digunakan jika masalah belum jelas, untuk mengetahui makna yang tersembunyi, untuk memahami interaksi sosial, untuk mengembangkan teori, untuk memastikan kebenaran data dan untuk meneliti sejarah perkembangan (Darmadi 2014). Strategi dari pendekatan kualitatif yang digunakan dalam penelitian ini adalah studi kasus. Yin (1996) mendefinisikan studi kasus sebagai suatu inkuiri empiris yang menyelidiki fenomena di dalam konteks kehidupan nyata bilamana batasbatas antara fenomena dan konteks tak tampak dengan tegas dan dimana multi sumber bukti dimanfaatkan melalui penekanan pada bentuk pertanyaan "bagaimana" dan "mengapa" tanpa melakukan kontrol peristiwa. Pada penelitian studi kasus, tidak digunakan istilah populasi karena penelitian ini ingin melihat sesuatu yang terjadi pada situasi sosial secara mendalam bukan untuk mengeneralisir analisis secara statistik melainkan untuk mengeneralisir analisis 
secara analitik yaitu mengembangkan atau melakukan generalisasi terhadap teori (Yin 1996).

Fokus penelitian pada penelitian ini adalah komunikasi pedagogis yang berlangsung pada Fakultas Kehutanan X. Pengambilan sampel dilakukan secara purposif, artinya menggunakan kriteria-kriteria yang telah ditetapkan terlebih dahulu sehingga informasi yang diterima dari sampel tersebut dapat lebih berkualitas (Irawan 2006). Unit penyelidikan pada penelitian ini diambil dari sampel dengan kriteria yaitu mahasiswa semester 7 yang telah mengambil mata kuliah X pada semester 5, mata kuliah Y pada semester 6 dan mata kuliah Z pada semester 7 dengan ditambahkan pembagian latar belakang mahasiswa yaitu aktivis dan bukan aktivis. Adapun sumber bukti yang dikumpulkan untuk memperkuat temuan dalam penyelidikan yang dilakukan dalam penelitian ini adalah sebagai berikut:

1. Observasi kelas sebanyak 3 kali pertemuan.

2. Wawancara mendalam dengan 3 mahasiswa semester 7 berlatar belakang aktivis.

3. Wawancara mendalam dengan 3 mahasiswa semester 7 berlatar belakang bukan aktivis.

4. Wawancara mendalam dengan 2 dosen pengajar mata kuliah berbasis eksakta.

5. Wawancara mendalam dengan 2 dosen pengajar mata kuliah berbasis sosial.

6. Studi dokumen pendukung seperti bahan kuliah, daftar hadir, kontrak perkuliahan, buku panduan program sarjana tahun 2016 dan buku pedoman mutu fakultas kehutanan.

7. Fokus Grup Diskusi dengan 10 mahasiswa semester 7.

Analsis data pada penelitian ini menggunakan analisis deskriptif. Analisis deskriptif dilakukan untuk memperoleh temuan-temuan penting dari data yang telah dikumpulkan untuk menggambarkan proses belajar mengajar di Fakultas Kehutanan $X$ serta berbagai epistemologi yang melatarbelakanginya. Irawan (2006) menyebutkan bahwa analisis deskriptif dapat dilakukan dengan 7 langkah yaitu pengumpulan data mentah, transkrip data, pembuatan koding, kategorisasi data, penyimpulan sementara, triangulasi dan penyimpulan akhir.

\section{HASIL DAN PEMBAHASAN}

Dalam konteks komunikasi, setiap terdapat suatu peristiwa komunikasi maka hal utama yang harus diperhatikan adalah efektif atau tidaknya proses komunikasi yang berlangsung. Apabila ditemukan ketidakefektifan maka penyelidikan atas berbagai persoalan yang melatarbelakanginya perlu dilakukan supaya dapat dimengerti konteks persoalannya sehingga lebih tepat dalam penggunaannya untuk pengambilan tindakan selajutnya.

Efektifitas komunikasi dalam penelitian kualitatif tidak ditunjukkan melalui data berupa angka-angka melainkan melalui penyajian fakta-fakta kontekstual yang terjadi. Dalam konteks pendidikan kritis, efektifitas komunikasi merujuk pada dua hal utama yaitu bagaimana membangun komunikasi untuk mengetahui (how to know) dan bagaimana membangun komunikasi untuk menumbuhkan kesadaran (how to transform) (Freire 2002, Freire 2016). 


\section{Gambaran Umum Unit Analisis}

Penelitian ini menyelidiki 3 mata kuliah beserta fenomena yang terjadi di dalamnya sebagai satu kesatuan unit analisis. Adapun gambaran umum ketiga mata kuliah tersebut disajikan pada tabel 3.1.

Tabel 1 Gambaran umum unit analisis

\begin{tabular}{|c|c|c|c|}
\hline Temuan & MK. X & MK. Y & MK. Z \\
\hline Jumlah & 4 & 4 & 2 \\
\hline $\begin{array}{l}\text { Komunikator } \\
\text { Jumlah } \\
\text { Komunikan }\end{array}$ & 51 & 100 & 97 \\
\hline Capaian & $\begin{array}{l}\text { Beragam bentuk } \\
\text { interaksi masyarakat } \\
\text { dengan tipe hutan, } \\
\text { beragam kemampuan } \\
\text { adaptasi masyarakat } \\
\text { dengan SDH dan } \\
\text { Stakeholders, } \\
\text { kebijakan dan praktik } \\
\text { pengembangan } \\
\text { partisipasi masyarakat, } \\
\text { dan beragam skema } \\
\text { partisipasi dalam } \\
\text { SFM. }\end{array}$ & $\begin{array}{l}\text { Beragam konsep } \\
\text { pengelolaan hutan berbasis } \\
\text { ekosistem (PHBE), } \\
\text { perencanaan kehutanan } \\
\text { dalam PHBE, } \\
\text { penatagunaan hutan, } \\
\text { pembentukan unit } \\
\text { pengelolaan hutan, } \\
\text { penetapan tujuan } \\
\text { pengelolaan hutan, } \\
\text { metoda pengaturan hasil, } \\
\text { penetapan preskripsi } \\
\text { pengelolaan hutan, monev } \\
\text { dalam pengelolaan hutan. }\end{array}$ & $\begin{array}{l}\text { Konsep kebijakan } \\
\text { pengelolaan } \\
\text { sumberdaya } \\
\text { hutan, } \\
\text { menjelaskan } \\
\text { permasalahan } \\
\text { pengelolaan } \\
\text { sumberdaya } \\
\text { hutan, memahami } \\
\text { pilihan kebijakan } \\
\text { yang optimal. }\end{array}$ \\
\hline
\end{tabular}

Proses komunikasi pedagogis di perguruan tinggi berlangsung dalam kerangka komunikasi kelompok sebagaimana yang terjadi juga pada ketiga mata kuliah tersebut. Komunikasi kelompok sendiri dimaknai sebagai komunikasi yang berlangsung antara 3 orang atau lebih yang mempunyai tujuan bersama, dalam waktu yang sama dan untuk memperoleh maksud yang sama (Mulyana 2000). Komunikasi kelompok berdasar jumlah pesertanya terbagi menjadi 2 yaitu komunikasi kelompok kecil dan komunikasi kelompok besar. Komunikasi kelompok kecil didefinisikan sebagai komunikasi kelompok dengan anggota yang saling mengenal, memiliki kedekatan emosional, mampu terjadi dialog yang terus menerus dan berlangsung secara fleksible, sedangkan komunikasi kelompok besar didefinisikan sebagai komunikasi kelompok dengan anggota yang tidak keseluruhannya saling mengenal, kurang memiliki kedekatan emosional (kedekatan formal), dialog sulit terjadi dan berlangsung secara formal/ searah (Mulyana 2000). Besar kecilnya kelompok bersifat imajiner berdasarkan keterpenuhan ciri-ciri dari kedua jenis komunikasi tersebut. Oleh sebab itu, kreativitas dan kemampuan komunikator dalam memimpin komunikasi agar dapat berjalan secara efektif menjadi salah satu kunci utama (Ardianto dkk 2007, Wisman 2017).

Pendidikan kritis sebagaimana harus memenuhi how to know dan how to transform, akan menjadi lebih mudah tercapai apabila bentuk komunikasinya dapat berlangsung sebagai komunikasi kelompok kecil karena aspek kedekatan dan dialogisnya dapat lebih mudah dalam membantu memahami dan membangkitkan kesadaran. Pada mata kuliah yang dianalisis sebagaimana 
disajikan pada tabel 1, dapat dipahami bahwa 1 orang komunikator memiliki anggota kelompok sebanyak 50-100 orang dengan beban capaian tujuan komunikasi cukup banyak dan dijalankan secara formal. Ciri-ciri yang muncul pada ketiga unit analisis tersebut mengarah pada bentuk komunikasi kelompok besar.

\section{Efektivitas Komunikasi}

Efektivitas komunikasi dapat dilihat melalui fakta-fakta yang terjadi dalam proses komunikasi. Sesuai dengan konsep efektivitas komunikasi pedagogis kritis sebagaimana telah disebutkan diatas yang terbagi menjadi keberterimaan pengetahuan dan pengembangan kesadaran sebagai hasil komunikasinya, maka dalam penelitian ini diungkap fakta-fakta yang dapat menunjang kedua hal tersebut sebagaimana disajikan pada tabel 3.2.

Tabel 2 Ragam metode penyampaian pesan

\begin{tabular}{|c|c|c|c|}
\hline Temuan & MK. X & MK. Y & MK. Z* \\
\hline Pesan & $\begin{array}{l}\text { Pendahuluan, landasan } \\
\text { kehutanan masyarakat, } \\
\text { penyuluhan, PRA, } \\
\text { metode wawancara. }\end{array}$ & $\begin{array}{l}\text { Pendahuluan, perubahan } \\
\text { kawasan hutan, } \\
\text { penatagunaan dan tata } \\
\text { ruang, pembentukan } \\
\text { wilayah dan zonasi, } \\
\text { prinsip kelestarian, } \\
\text { sistem silvikultur dan } \\
\text { struktur tegakan, } \\
\text { pengaturan multiguna } \\
\text { hutan, sertifikasi hutan, } \\
\text { management plan, kapita } \\
\text { selekta, monev, } \\
\text { pengaturan hasil. }\end{array}$ & $\begin{array}{l}\text { Pengertian kebijakan, } \\
\text { elemen kebijakan, } \\
\text { teori pengambilan } \\
\text { keputusan, analisis } \\
\text { dan sintesis kebijakan, } \\
\text { analisis konflik } \\
\text { pembuatan kebijakan, } \\
\text { paradigma dan } \\
\text { instrumen kebijakan. }\end{array}$ \\
\hline Metode & Metode 1 (M1) & Metode (M2) & Metode (M3) \\
\hline Komunikasi & $\begin{array}{l}\text { Penyampaian: } \\
\text { menjelaskan. } \\
\text { Bahasa: } \\
\text { Mudah dimengerti. } \\
\text { Dialog interaktif: } \\
\text { Terjadi. } \\
\text { Metode } 2 \text { (M2) } \\
\text { Penyampaian: } \\
\text { membaca. } \\
\text { Bahasa: } \\
\text { Kurang dimengerti. } \\
\text { Dialog interaktif: } \\
\text { Tidak terjadi. }\end{array}$ & $\begin{array}{l}\text { Penyampaian: membaca. } \\
\text { Bahasa: } \\
\text { Kurang dimengerti. } \\
\text { Dialog interaktif: } \\
\text { Tidak terjadi. }\end{array}$ & $\begin{array}{l}\text { Penyampaian: } \\
\text { menjelaskan. } \\
\text { Bahasa: } \\
\text { Kurang dimengerti. } \\
\text { Dialog interaktif: } \\
\text { Belum terjadi. }\end{array}$ \\
\hline $\begin{array}{l}\text { Akumulasi } \\
\text { pengetahuan }\end{array}$ & $\begin{array}{l}\text { Teknik PRA, } \\
\text { Pemanfaatan lahan } \\
\text { terlantar (cerita), } \\
\text { selebihnya lupa. }\end{array}$ & $\begin{array}{l}\text { Berhitung tapi tidak tahu } \\
\text { untuk apa, sertifikasi, } \\
\text { selebihnya lupa. }\end{array}$ & Lupa. \\
\hline Penyadaran $^{* *}$ & Tidak ada. & Tidak ada. & Belum ada. \\
\hline
\end{tabular}

*Mata kuliah masih berlangsung.

**Penyadaran: belajar memahami dan mendialogkan pertentangan pandangan dalam suatu situasi yang mengarah pada pengungkapan ketidakadilan (Freire 2002, Freire 2016). 
Dari fakta yang diperoleh, ternyata masih terdapat gap yang cukup berarti antara pesan yang disampaikan dengan keberterimaan pesan tersebut (how to know). Dari keseluruhan pesan yang disampaikan selama 14 kali pertemuan dengan target capaian kompetensi seperti yang telah disebutkan pada tabel 1 , ternyata komunikan hampir tidak memiliki ingatan atas pesan yang telah disampaikan pada mata kuliah yang diselidiki baik yang berlangsung pada semester 5, semester 6 bahkan yang baru saja selesai mengikuti proses komunikasi pedagogis pada hari itu.

"mudah dimengerti si, tapi lupa. Aku merhatiin kemarin nyatet juga tapi enggak diinget gitu. Isinya si hafalan, lebih ke nerangin gitu.” (MS, 3

Oktober 2018)

Pada tataran penyadaran (how to transform), tidak diperoleh proses yang dianggap informan membahas pesan yang memancing dialog sehingga tidak terjadi proses pengembangan pengetahuan dan berpikir kritis secara subjektif dan tidak bebas nilai pada suatu pokok bahasan. Komunikasi juga tidak mengarah pada mencari situasi ketidakadilan dalam pengelolaan hutan yang diungkap dari berbagai sisi.

"Enggak ada tanya jawab kang, sedikit banget yang merhatiin. Kalau Pak HP karna takut ditanya aja jadi rata-rata merhatiin karna kadang nanya sampai belakang-belakang. Kalau yang lain dikit banget. Aku sampe nanya ke temen-temen, ini belajar apa sih sebenere, kaya gini nih sebenere belajar apa, pada gak ngerti juga, yaudah deh gitu jadinya." (MS, 3 Oktober 2018)

\section{Persoalan Komunikasi}

Dari fakta-fakta yang telah diungkap, menunjukkan adanya situasi yang mengarah pada ketidakefektifan komunikasi pedagogis. Oleh sebab itu perlu diselidiki berbagai persoalan yang memungkinkan menjadi konstruk ketidakefektifan komunikasi tersebut. Berikut ini disajikan temuan berbagai persoalan yang menjadi latar situasi ketidakefektifan komunikasi pedagogis pada konteks unit analisis yang diteliti.

a. Jumlah komunikan

Jumlah komunikan yang terlalu banyak menjadi hambatan bagi komunikator untuk dapat menyampaikan pesan secara efektif. Hal tersebut menjadi penyebab timbulnya sympton bola salju yang memunculkan masalah-masalah baru. Sistem yang menghendaki jumlah mahasiswa setiap tahunnya meningkat membuat jumlah komunikan melebihi kapasitas kemampuan komunikator untuk dapat berimprovisasi secara kreatif. Hal tersebut juga diperparah dengan keterbatasan tempat, keterbatasan jumlah komunikator dan juga keterbatasan waktu.

Banyaknya jumlah mahasiswa dalam satu mata kuliah dan banyaknya materi yang harus disampaikan merupakan bagian dari efisiensi komunikasi namun berbanding terbalik dengan efektivitas komunikasinya. Oleh sebab itu diperlukan improvisasi yang lebih kreatif lagi dari komunikator untuk dapat menghadapi situasi tersebut supaya tujuan komunikasi pedagogis dapat tercapai. Capaian mata kuliah akan menjadi terdistorsi apabila hanya disandarkan pada keberhasilan mendapatkan kelulusan dari nilai mutu akhir yang dapat diperoleh 
dari ujian yang bersifat hafalan. Oleh sebab itu dapat ditawarkan konsep bahwa efektivitas merupakan rasio dari kreativitas dengan efisiensi.

$$
\text { Efektivitas }=\frac{\text { Kreativitas }}{\text { Efisiensi }}
$$

"Karna kuliahnya massal, ini implikasinya bertubi-tubi mulai dari situasi yang tidak kondusif, tidak bisa interaktif mengenal satu dengan lainnya, sampai dalam hal membuat soal ujian." (BP, 8 Oktober 2018)

b. Kemudahan lulus mata kuliah

Jumlah mahasiswa yang banyak telah menjadikan komunikator menyesuaikan diri dalam membuat soal ujian menjadi lebih sederhana karena keterbatasan waktu dan efisiensi penilaian. Hal tersebut ternyata menimbulkan efek bagi mahasiswa bahwa mudahnya mendapatkan kelulusan pada mata kuliah, menyebabkan kuliah itu sendiri tidak menjadi penting dan sekedar formalitas untuk dapat memenuhi kewajiban absensi. Disisi lain sistem yang menghendaki lulus cepat dan menghindari biaya kuliah tinggi membuat penyederhanaan perkuliahan yang efisien menjadi kurang efektif.

"kami kan susah juga untuk membuat soal yang tingkatnya esai yang menganalisis karena banyaknya mahasiswa, terkendala keterbatasan waktu untuk mengoreksi dan harus cepat-cepat dimasukkan nilainya." (BP, 8 Oktober 2018)

"iya bang, soalnya kan ujian bisa sks juga ngerjainnya baca slide, yang penting bisa ngerjain ujian jadi kalau gak suka ya gak merhatiin” (IR, 2 Oktober 2018)

\section{c. Gap sosiopsikologis}

Masih ditemukan bahwa terdapat kecanggungan dari mahasiswa untuk bertanya kepada dosen karena takut pertanyaannya salah, tidak baik ataupun dianggap tidak memperhatikan termasuk canggung bertanya kepada profesor. Ketidakpahaman yang dipikirkan komunikan dan tidak mampu tersampaikan akhirnya membuat mahasiswa tidak lagi tertarik untuk mengikuti perkuliahan karena merasa telah tertinggal. Dosen yang cara komunikasinya kaku dan kurang interaktif, bagi mahasiswa dianggap menimbulkan gap untuk bertanya dan berinteraksi. Disisi lain, pengaruh keberadaan komunikan lain yang heterogen dan banyak, juga membuat mahasiswa enggan untuk bertanya karena takut muncul adanya intervensi atas tindakan bertanya yang dilakukan.

"Ada kadang canggung kalau dosennya profesor kadang ngerasanya mereka prof, mau tanya takut yang ditanyakan udah dijelaskan jadi bingung, ragu, karna dia udah profesor. Cuma ada juga yang gak takut kalau dosennya lebih interaktif dan bahasannya mudah diterima kaya implementasi 2 jadi nyambung mau nanya, tertantang buat nanya. Kalau profesor dan teori, ragu takut gak nyampe mau nanya."(ML, 2 Oktober 2018)

"bukan hanya itu, tapi juga membutuhkan keberanian mahasiswa untuk bertanya didepan teman-temannya karena kadangkan tau sendirilah kalau 
nanya nanti diintimidasi sama temen-temennya, jadi keaktifannya juga sangat personal membutuhkan keberanian." (DR, 15 Oktober 2018)

d. Stres pendidikan

Mengadopsi pada teori stres lingkungan yang menyatakan bahwa karakteristik lingkungan memiliki relasi terhadap individu apakah situasinya menimbulkan stres atau tidak beserta respon stres yang ditimbulkannya (Sarwono 1992), situasi pendidikanpun dapat dilihat demikian. Tekanan dalam proses pendidikan yang berlebihan membuat mahasiswa memberikan respon balik yang negatif atas proses pendidikan yang berlangsung. Materi yang banyak pada setiap kuliah, jumlah mata kuliah yang banyak, tugas kuliah yang banyak dan aktivitas lain yang membutuhkan fokus berlebih secara bersamaan bagi sebagian mahasiswa menjadi stimulus stres dalam pendidikan yang akhirnya memberikan respon menurunnya fokus dalam mengikuti perkuliahan.

"Semester ini saya bener-bener belum bisa fokus mas, banyak banget yang harus dikerjain jadi kurang ngikutin." (AA, 3 Oktober 2018)

"Sekarang kan banyak mata kuliah digabung-gabung jadi materinya lebih padat, waktunya juga terbatas untuk menyampaikan. Kalau mahasiswa sekarang saya perhatikan ya 3D: datang, duduk diem, jarang yang aktif bertanya." (BK, 27 Mei 2018)

e. Kesiapan dan pesan baru

Pesan tentang kehutanan yang disampaikan bagi sebagian mahasiswa adalah hal yang baru dan tidak familiar sehingga imajinasi mahasiswa tidak mampu bangkit untuk dapat memunculkan pertanyaan dan dialog. Hal tersebut membuat mahasiswa lebih memilih diam, mencatat dan mendengarkan apapun yang disampaikan oleh komunikator. Disisi lain, literasi mahasiswa tentang kehutanan/ pengetahuan umum juga masih sangat sedikit sebagai persiapan mengikuti perkuliahan sehingga dialog menjadi lebih susah untuk dipancing.

"Bingung juga si kang, kadang mau nanya apa juga bingung jadi terimaterima aja. ... Paling denger-denger sama baca-baca di medsos kalau penasaran baru cari tahu. ... gak suka baca buku si. ... kemarin disuruh baca buku juga pas matkul Z tapi aku gak baca jadi gak ngikuti." (IR, 2 Oktober 2018)

"mahasiswa juga sekarang minim literasi, ... pengetahuan umumnya saja sekarang rendah sekali, .... tidak ada persiapan untuk mengikuti perkuliahan, kalaupun ada debat juga tidak punya bekal jadinya debat kusir.” (DR, 2 Oktober 2018)

\section{f. Ketidaktertarikan}

Hal yang tidak disukai dan tidak tahu fungsinya akan cenderung ditinggalkan atau dilupakan. Mahasiswa yang lupa terkait isi pesan yang telah disampaikan menyatakan bahwa karena kuliah dan ujian telah usai maka materi tidak lagi diingat. Pesan pembangunan tidak tersampaikan fungsinya sehingga penerimaannya hanya untuk keperluan jangka pendek yaitu lulus mata kuliah tersebut.

"kenapa lupa ya karena udah selesai kuliahnya kang, udah gak diajarkan lagi. Dibaca-bacanya pas mau ujian aja.” (IR, 2 Oktober 2018) 


\section{g. Perbedaan latar belakang}

Latar belakang dalam berpendidikan memiliki konstruk yang kuat dalam membangun motivasi mahasiswa untuk mengikuti dan terlibat secara aktif dalam komunikasi pedagogis yang berlangsung. Latar belakang ini dapat berupa latar belakang individunya maupun relasi sosial serta pengalaman-pegalamannya yang bagi mahasiswa memiliki penekanan menonjol pada ingatan serta kebiasaannya. Dalam penelitian ini ditemukan bahwa latar belakang mahasiswa yang dalam memilih jurusan diperguruan tinggi dipilihkan oleh orang tuanya memberi dampak pada kurang tertariknya mahasiswa mengkuti perkuliahan menjadi lebih pasif. Disisi lain, kebiasaan orang tua berdiskusi dengan anaknya saat makan bersama dan berkumpul di rumah, menjadi faktor pendorong mahasiswa tersebut juga aktif bertanya saat mengikuti perkuliahan. Namun demikian, faktor latar belakang ini bukanlah faktor tunggal karena ditemukan juga sesama mahasiswa yang berlatar belakang organisasi ternyata memiliki variasi bahwa salah satunya aktif sedang salah satunya tidak aktif. Hal tersebut tentu menunjukkan perlu pendetailan dalam pengamatan latar belakang individu dalam setiap latar belakang yang mendorongnya memilih pilihan perilaku tertentu.

"saya sebenere kang, itu masuk ke sini kan disuruh ibu. Jadi ya udahlah ngikut-ngikut aja. Jadi ya kurang tau gitu sebenere. .... iya karna ibuk kerja disini kan." (ML, 2 Oktober 2018)

"iya mas, apa ya soalnya udah biasa si dirumah suka ngobrol-ngobrol sama bapak ibu ditanyain ini itu kalau pas ngumpul. Soalnya kan ibu juga kerja dikehutanan juga jadi nyambung." (AA, 3 Oktober 2018)

\section{h. Otonomi individu dan keilmuan tidak optimal}

Dosen memiliki ruang otonomi tersendiri baik dalam cara menyampaikan pesan maupun membentuk pesan itu sendiri. Tidak ada yang mengawasi dan membatasi apa yang dosen lakukan dan sampaikan di dalam kelas sehingga kreativitas dari dosen itu sendirilah yang menentukan efektif atau tidaknya komunikasi pedagogis yang berlangsung.

"saya kan walau koordinator mata kuliah juga tidak mungkin ngatur-ngatur dosen lain atau nongkrongin dosen lain pas lagi ngajar, semua punya otonomi keilmuan sendiri dalam mengajar walaupun kadang materi yang disampaikan juga tumpang tindih tapi kami membatasi dengan silabus yang sudah dibuat bersama." (DR, 15 Oktober 2018)

\section{Implikasi Komunikasi Sebagai Hipotesis Lanjutan}

a. Tidak tersampaikannya pesan pembangunan

Atas kondisi dan fakta yang telah dipaparkan diatas terkait ketidakefektifan komunikasi dan berbagai persoalan-persoalan yang melatarbelakanginya, terdapat implikasi yang cukup berbahaya apabilan terus dibiarkan. Tujuan utama komunikasi pedagogis sebagai wujud dari komunikasi pembangunan menjadi tidak dapat tercapai. Pendidikan sebagai proses untuk menyiapkan generasi penerus yang mampu menghadapi dan berkontribusi terhadap pembangunan kehutanan menjadi tidak siap secara keilmuan karena tidak tersampaikannya dan tidak berkembangnya pengetahuan kehutanan yang berlangsung di perguruan tinggi kehutanan. Perkuliahan semestinya menjadi media utama dalam melakukan transaksi pesan dan pengembangan pesan kehutanan secara kontekstual di pendidikan tinggi, adapun kegiatan aktivisme dan pengalaman lainnya adalah 
penunjangnya, namun yang terjadi aktivisme dan pengalamanlah yang justru menjadi media utama mahasiswa dalam memperoleh pengetahuan dan bersikap dalam berbagai persoalan kehutanan. Bukan berarti situasi demikian salah namun alangkah tidak tepatnya apabila perkuliahan menjadi tindak memiliki fungsi yang berdaya untuk membangun pengetahuan dan sikap dalam pembangunan kehutanan dimasa mendatang. Untuk itu perlu adanya improvisasi baru dalam konteks membangun komunikasi pedagogis yang lebih dapat diterima oleh mahasiswa era milenial saat ini supaya tidak menjadi lulusan dengan keahlian semu yang dilegitimasi oleh ijazah (awam namum dianggap ahli).

"setelah 7 semester kuliah ya, duh bingung juga Bang, ngerasa belum dapat apa-apa aja nih, belum nguasai apapun, nanti kalau kerja ya ngikutin aturan aja kaya gimana." (MS, 3 Oktober 2018)

\section{b. Hilangnya kekritisan}

Tidak sampainya komunikasi pedagogis pada tahap penyadaran tentu akan membuat mahasiswa tidak menerima informasi situasi kontekstual dalam pembangunan kehutanan serta berbagai hal yang mengarahkan pada sumber persoalan, ketidakadilan dan penindasan. Komunikasi pedagogis hanya selesai pada level administratif yaitu selesai mengajar dan mahasiswa mampu lulus dengan mengerjakan ujian. Mahasiswa seperti dilepaskan dari realitas dan persoalan yang ada secara tidak sadar sehingga tidak mampu berpikir kritis sebagaimana yang disampaikan oleh Rahimi dan Sajed (2014) tentang berpikir kritis yaitu kondisi dimana seseorang mampu menghidari pendapat bodoh dengan membedakan fakta dan opini, menanyakan tentang dasar-dasar argumentasi serta mengambil kesimpulan secara hati-hati. Situasi yang ada masih mengarah pada pendidikan gaya bank yang menghidupkan budaya bisu sebagaimana diungkap oleh Freire (Freire 2002, Freire 2012). Pada prosesnya, sesuailah dengan yang disampaikan oleh Soedomo (2013) bahwa pendidikan tinggi justru lebih berperan sebagai institusi pelestari hipnotis massal dengan meningkatkan kognitif (administratif) namun mematikan jiwa.

\section{KESIMPULAN DAN SARAN}

\section{Kesimpulan}

Hasil analisis menunjukkan bahwa masih terjadi ketidakefektifan komunikasi pedagogis yang berlangsung pada obyek yang diteliti dan mengarah pada konsep pendidikan gaya bank. Ketidakefektifan tersebut disebabkan oleh setidaknya 8 hal yang terungkap yaitu jumlah komunikan, kemudahan lulus mata kuliah, gap sosiopsikologis, stres pendidikan, ketidaksiapan dan kebaruan pesan, ketidaktertarikan dan otonomi individu dan keilmuan yang tinggi namun tidak teraktualisasi dengan optimal. Ketidakefektifan komunikasi pedagogis yang terus dibiarkan membuat persoalan komunikasi menjadi tidak tampak serius di perguruan tinggi. Pesan pembangunan menjadi tidak tersampaikan secara kontekstual dan membuat mahasiswa menjadi kurang siap menghadapi tantangan persoalan pembangunan kehutanan di masa mendatang. Pendidikan tinggi kehutanan memiliki tanggung jawab untuk menjawab berbagai tantangan persoalan kehutanan salah satunya dalam memperbaiki komunikasi pedagogis yang berlangsung di dalamnya. 


\section{Saran}

Penelitian komunikasi pembangunan dengan fokus pada penyelenggaraan pendidikan tinggi harus diperkuat dan dikembangkan secara transdisiplin sehingga dapat semakin memperjelas temuan berbagai persoalan ketidakefektifan komunikasi pedagogis secara mendetail disetiap unsur-unsurnya sebagai autokritik perbaikan penyelenggaraan pendidikan tinggi.

\section{DAFTAR PUSTAKA}

Afiff S. 2005. Mengintegrasikan Perspektif Sosial Politik dalam Kurikulum Pendidikan Tinggi Kehutanan. Dalam Forum Pimpinan Lembaga Pendidikan Tinggi Kehutanan [fOReTIKA] (ed). Transformasi Pendidikan Tinggi Kehutanan Indonesia (pp. 28-35). Bogor (ID): Foretika dan DFID.

Aldian DG. 2002. Menyoal Objektivitas Ilmu Pengetahuan dari David Hume Sampai Thomas Kuhn. Jakarta (ID): Penerbit Teraju.

Ardianto, Elvinaro, Komala L, Karlinah S. 2007. Komunikasi Massa: Suatu Pengantar. Bandung (ID): Simbiosa Rekatama Media.

Darmadi H. 2014. Metode Penelitian Pendidikan dan Sosial: Teori Konsep Dasar dan Implementasi. Bandung (ID): Penerbit Alfabeta Bandung.

De Bono, E. 2009. Lateral Thinking: A Textbook of Creativity. London (UK): Penguin Books Limited.

[DEPHUT] Departemen Kehutanan. 2009. Eksekutif Data Strategis Kehutanan 2009. Jakarta (ID): Departemen Kehutanan.

Dilla S. 2007. Komunikasi Pembangunan Pendekatan Terpadu, Cetakan Pertama. Bandung (ID): Simbiosa Rekatama Media.

[fOReTIKA] Forum Pimpinan Lembaga Pendidikan Tinggi Kehutanan. 2005. Pendahuluan. Dalam Forum Pimpinan Lembaga Pendidikan Tinggi Kehutanan [fOReTIKA] (ed). Transformasi Pendidikan Tinggi Kehutanan Indonesia (pp. 5-6). Bogor (ID): Foretika dan DFID.

Freire P. 2002. Politik Pendidikan: Kebudayaan, Kekuasaan, Pembebasan, Cetakan Ketiga. (Terjemahan) Yogyakarta (ID): Read dan Pustaka Pelajar.

2016. Pendidikan Kaum Tertindas, Cetakan Kedelapan. (Terjemahan). Jakarta (ID): Pustaka LP3ES Indonesia.

[FWI] Forest Watch Indonesia. 2013. Potret Keadaan Hutan Indonesia 20092013. Bogor (ID): FWI.

Gluck P. 1987. Social Values in Forestry. Ambio. 16(3):158-160.

Hadiyanto. 2008. Komunikasi Pembangunan Partisipatif: Sebuah Pengenalan Awal. Jurnal Komunikasi Pembangunan. 6(2): 80-88.

Hidayat R. 2013. Pedagogi Kritis: Sejarah, Perkembangan dan Pemikiran. Jakarta (ID): PT. Raja Grafindo Persada.

Ina M. 2011. Analisis Konflik Sumberdaya Hutan di Kawasan Konservasi. Sodality. 5(1):90-96.

Irawan P. (2006). Penelitian Kualitatif dan Kuantitatif untuk Ilmu-Ilmu Sosial. Depok (ID): DIA FISIP UI. 
Kartodihardjo H. 2013. Masalah Cara Pikir dan Praktek Kehutanan: Refleksi dan Evaluasi II. Dalam: Kartodihardjo H (ed). Kembali ke Jalan Lurus Kritik Penggunaan Ilmu dan Praktek Kehutanan Indonesia (pp. 477-497). Yogyakarta (ID): Forci Development dan Tanah Air Beta.

Konsorsium Pembaruan Agraria. 2014. Catatan Akhir Tahun 2014 Membenahi Masalah Agraria: Prioritas Kerja Jokowi-Jk Pada 2015. Jakarta (ID): KPA.

Marina I, Dharmawan AH. 2011. Analisis Konflik Sumberdaya Hutan di Kawasan Konservasi. Sodaliti. 01(5): 90-96.

Mulyana D. 2000. Ilmu Komunikasi Suatu Pengantar. Bandung (ID): PT. Remaja Rosdakarya.

Nugroho B. 2011. Land Rights of Community Forest Plantation Policy: Analysis from an Institutional Perspective. JMHT. 17(3): 111-118.

. 2017. Akselerasi Implementasi Program Perhutanan Sosial: Sebuah Telaah Efektivitas Kebijakan dan Kelembagaan. Presentasi dalam Seminar Strategi Perhutanan Sosial dalam Rangka Mewujudkan Pengelolaan Hutan Berkelanjutan untuk Meningkatkan Kesejahteraan Masyarakat. Jakarta, 20 Desember 2017.

Oey-Gardiner M, dkk. 2017. Era Disrupsi Peluang dan Tantangan Pendidikan Tinggi Indonesia. Jakarta (ID): Akademi Ilmu Pengetahuan Indonesia.

Prucha J. 1986. Pedagogical Communication and Pedagogical Interaction: A Survey of Theory and Empirical Research in Czechoslovakia. EJPE. 1(1): 91-100.

Rahimi A, Sajed MA. 2014. The Interplay between Critical Pedagogy and Critical Thinking: Theoretical Ties and Practicalities. Procedia-Social and Behavioral Sciences. 136:41-45.

Rinawati R. 2006. Komunikasi dan Pembangunan Partisipatif. Mediator. 7(2): 175-184.

Sastrosumarto S. 2005. Beberapa Catatan Mengenai Pengalaman Menyusun Kurikulum Nasional dan Pengimplementasiannya. Dalam: Forum Pimpinan Lembaga Pendidikan Tinggi Kehutanan [fOReTIKA] (ed). Transformasi Pendidikan Tinggi Kehutanan Indonesia (pp. 66-70). Bogor (ID): Foretika dan DFID.

Santoso I. 2008. Zooning Area Hutan dan Konfliknya. J Peneliti Sos Ekon Kehutanan. 5(3): 143-153.

Setiawan EN, Maryudi A, Purwanto RH, Lele G. 2017. Tipologi dan Kerawanan Korupsi Sektor Kehutanan di Indonesia. Jurnal Ilmu Kehutanan. (2):142155. https://jurnal.ugm.ac.id/jikfkt.

Soedomo S. 2010. Perum Perhutani di Kala Senja. Tidak dipublikasikan.

. 2012. Obrolan Nusantara: Menyambut Indonesia Baru. Bogor (ID): Forci Development dan Firdaus.

2013. Scientific Forestry. Dalam: Kartodihardjo H (ed). Kembali ke Jalan Lurus Kritik Penggunaan Ilmu dan Praktek Kehutanan Indonesia (pp. 49-77). Yogyakarta (ID): Forci Development dan Tanah Air Beta. 
pISSN 1693-3699

Jurnal Komunikasi Pembangunan

elSSN 2442-4102

Juli 2018, Volume 16, No. 2

Suharjito D. 2011. Proses Penyelesaian Sengketa Lahan Hutan: Suatu Kajian Antropologi Hukum. JMHT. 7(1).

Wisman Y. 2017. Komunikasi Efektif dalam Dunia Pendidikan. Jurnal Nomosleca. 3(2): 645-654.

2014. Pengantar Metodologi Penelitian. Bogor (ID): IPB Press.

Yin RK. 1996. Studi Kasus Desain dan Metode [terjemahan]. Jakarta (ID): PT Raja Grafindo Persada. 